\title{
Media Policy for Private Media in the Age of Digital Platforms
}

\begin{abstract}
Digital platforms such as Google, Facebook, and Netflix have caused a watershed moment not only for markets and businesses, but also for media policy. Concerns about the USbased digital platforms' impact on national media markets have grown among European media businesses as well as policy makers. Media policy research argue that small media markets are particularly vulnerable to global players and foreign influence, but that market size must be understood also in context of political traditions. This article investigates how digital platforms influence on media policy for private media businesses in the small media systems of Norway and Flanders. Drawing on 20 qualitative interviews with CEOs and top-level media managers in these two small media markets, we ask what private media businesses expect from policy makers in light of the intensified competition from digital platforms, what experience they have with cooperating with policy makers, and what explains the differences between Norway and Flanders. A key finding is that the managers in both markets want policy makers to regulate digital platforms to secure level playing field, and that the Norwegian respondents had more positive experiences with coregulation and expressed more trust in policy makers and policy instruments, compared to the Flemish. Despite the global players and the need for transnational solutions, regional variations in policy-making still matters, and might inform the discussion about how to regulate the digital platforms.
\end{abstract}

\section{Introduction}

Digital platforms such as Google, Facebook, and Netflix have caused a watershed moment not only for markets and businesses, but also for media policy. The global giants are disruptive because of their control over digital markets, and their expansive and innovative strategies. They operate as platforms that go well beyond the typical two-sided market structure of legacy media, but integrate functions within and across value chains to maximise control over revenue streams within and on the borders of the platform. Some 
of them have become dominant in areas such as social media and search, and thus gained 'platform power' in relation to states, politicians and policy makers, as well as legacy media companies (Moore \& Tambini, 2018). Facebook, for example, controls 60\% of all social media transactions worldwide, and has thus evolved into a platform by building complex ecosystems, or infrastructures, designed to capture as much of their users' attention and personal data as possible (Naughton, 2018; Plantin et al., 2018, p. 304).

The terms most commonly used to describe global companies such as Facebook, Google and Amazon are 'intermediaries', (Helberger et al. 2015; Moore \& Tambini 2018), 'infrastructures' (Platin et al., 2018), and 'digital platforms' (Mansell, 2015; Coyle 2018). Following Coyle (2018, p. 50), who argues that the latter "is the term increasingly used for hybrid entities using digital technology as an interface between the users or customers or a product and its suppliers", we will use 'digital platforms' in the subsequent discussions.

Concerns about the digital platforms' political and social implications have grown among politicians and policy makers, and initiatives to regulate them have been taken. Yet, even supranational regulatory bodies such as the European Union (EU) struggle to find efficient ways to regulate the dominance of digital platforms based in the USA. In relation to the US model for media regulation, with its preference for self-regulation, the European social model is more concerned with the public interest and has more extensive experience with co-regulation (Mansell, 2015; O’Regan \& Goldsmith, 2006; Zvoralska \& Davis, 2017; Barwide \& Watkins 2018, Tambini, 2016; Tambini \& Moore, 2018).

While existing research in this context has examined public broadcasters, media policy challenges, and digital platforms, we know little about but how domestic private media see the challenges and opportunities of this surrounding market. A key aim is to examine how the private media companies regard their situation in relation to policy makers and existing regulatory regimes, considering the intensified competition from digital platforms. More specifically, we ask: What characterizes private media companies' expectations from policy makers now they face intensified competition, what are their experiences from previous encounters with policy makers, and what are the key explanations of the differences between two small European media markets?

The research questions are discussed on the basis of a comparative study of two small European markets: Flanders, the semi-autonomous region in the Northern part of Belgium, and Norway, a part of the Nordic region. The study is a comparative analysis, of which the units of comparison are untypical in political studies (Gerring, 2013, p. 5). Norway is a nation state, and Flanders is a province of Belgium, but they are nevertheless 
comparative units because Belgium as a state has delegated media policies to the language communities, and the Belgian market is split between the French-speaking and Dutchspeaking market at the level of ownership and consumption (d'Haenens, Saeys \& Antoine, 2007). Both can be considered coordinated market economies, but the degree of intervention and public support for the media differs, with Norway spending more per capita on media (Brüggemann et al., 2014). Findings are based on qualitative elite interviews with 20 top-level media managers, strategically selected from key media sectors in Flanders and Norway. The analysis is divided in three sections; the first deals with expectations towards policy makers in a new competitive environment, the second with the managers' experiences with collaboration with policy makers, and the third discusses explanations of differences between the two media markets.

\section{Small media markets, different media systems}

Media policy research has a preference for typologies. Even if simplifying reality, they are useful as a starting point for analysis of key developments in media policy and how they relate to the general differences and similarities between media systems.

A key parameter is often size of the media market, more specifically the distinction between large and small media markets (Puppis et al., 2009; Lowe \& Nissen 2011). Research on small media systems was prominent in the late 1980s and early 1990s, when trends of deregulation, commercialisation and globalization were dominant (Puppis, 2009, p. 7). Again, European media markets are in transition; digital disruption and global giants challenge income models and regulatory regimes (Moore \& Tambini 2018). In this study we revisit the research on small media markets in the age of digital platforms, by analysing how recent market changes impact on media policies for private media in Flanders, the semi-autonomous region in the Northern part of Belgium ( 6.5 million inhabitants) and Norway, a country in the Nordic region (5 million inhabitants). As small language areas, Flanders and Norway have in common that they have higher vulnerability and dependency than larger markets, meaning for example that they are more affected by supranational decisions (Puppis et al., 2009, p. 107).

Smallness alone does not explain media regulation, and the small state perspective must be supplemented with the notion of different political and historic traditions (Puppis et al., 2009, p. 106). The similarities between Belgium and Norway extend to political economy and policy regimes; in a typology of political economies (Hall \& Soskice, 2001, p. 8) classify both Belgium and Norway as 'coordinated market economies', with a higher 
degree of coordination between business and state than in liberal market economies. Hallin and Mancini (2004) classify Belgium and Norway as 'Democratic Corporatist', given a relatively high degree of political parallelism, professionalization, protection of freedom of the press, and policies for the media. Both Flanders and Norway have developed comprehensive media policy measures to compensate for limited size and safeguard cultural identity, language development and economic sustainability (Puppis \& Künzler, 2013; Trappel, 2011, Lowe et al., 2011).

A body of studies nevertheless pinpoints differences between Belgium and Norway. Brüggemann et al. (2014, p. 1056-1057; see also Benson and Powers 2011; and Aalberg et al. 2012) argue that the level of funding of public service broadcasting and press subsidies is significantly lower in Belgium than Norway, and thus suggest that Norway should be classified as a prototype of what they define as the Northern cluster, while Belgium is classified in the Western cluster, together with the United States, Portugal, Ireland and the Netherlands. Although the differences are a matter of degree rather than fundamentals, Syvertsen et al. (2014) argue that the media in the Nordic countries is understood within the framework of the welfare state and suggest the term Media Welfare State to capture its distinctiveness; emphasis on universality, private-public cooperation and positive view of state intervention. In Norway, there is a presence of a wider normative framework, and political interventions in the media system protected by the state in order to fulfil policy goals and support the media as a public good (Larsen, 2011; Ohlsson, 2015; Ots et al., 2016; Allern \& Pollack, 2017). In comparison, the Flemish intervention in the media market can be characterized as a form of controlled liberalization, where government intervenes to achieve specific goals, as well as to curb market failure and prevent fullfledged liberalization. Policy aims to protect the linguistic and identity aspects of Flemish culture, but - and even more so - aims to protect the economic fabric of the domestic media sector. This results in policies that are steered by industry stakeholders and an overall objective to preserve the status quo. That approach is also referred to as the intent to safeguard the 'pax media', i.e. the fairly peaceful relationship between the different players in the value chain (author et al. 2017; author 2012).

\section{State regulation in the era of digital platforms}

State regulation is a key strategy for small markets to compensate for limited size and safeguard cultural identity, language development and economic sustainability (Puppis \& Künzler, 2013; Trappel, 2011, Lowe et al., 2011). A key question in contemporary policy 
studies is to what degree the role of the state in media regulation is decreased or increased in the age of digital platforms (Flew et al. 2016; Lynskey 2017; Moore \& Tambini 2018). New media challenge the very concept of defined international boundaries because of their 'borderless' architecture (Iosifidis, 2016, p. 23). Scholars even argue that digital platforms such as Google and Facebook have gained power on the level of 'souvereign entities equivalent to a nation' (Conti, 2009, p. 4; Moore \& Tambini, 2018). Yet, another body of research pinpoints the emergence of the regulatory state, arguing that "even though the role of the state has shifted from control of the media to maintaining, coordinating and facilitating developments through the provision of a regulatory framework, it still remains the dominant policy actor" (Flew et al., 2016, p. 9-10). The growth of digital platforms has nevertheless challenged the power of the nation state, not least because these players have been reluctant to be defined as media companies. The status as technology companies marginalizes the prominent societal and cultural dimensions of their operations (Tambini, 2016; Napoli \& Caplan, 2017; Lynskey, 2017). Although Facebook has admitted to some editorial responsibility after the Cambridge Analytica scandal (Bell, 2018), the outcome of such incidents tend to be self-regulation measures. In contrast to co-regulation which is more top-down, self-regulation is bottom-up, and has been characterized as a form of corporate social responsibility (Lievens 2006; Lievens 2010, Milosevic, 2017). Dominant digital platforms have in common that they are based in the USA and relate to US regulations, which are more light-touch, narrow and reactive regulatory model than the European model (Moore \& Tambini, 2018, p. 3). As such, there is a potential transatlantic conflict regarding the level of state involvement and co-regulation versus a more industrydriven self-regulation (Barwise \& Watkins, 2018, p. 55). Yet, there are significant differences between the models for regulation in European states (Hallin and Mancini, 2004; Syvertsen et al. 2014), and the policy contexts will impact on the degree of regulatory disruption caused by global platforms.

Again, a diverging factor is market size, because as Lowe et al (2011, p. 32) argue, "smaller markets only rarely determine the tide of affairs. They are most often on the 'receiving end' of international processes", and "larger markets are better able to withstand international pressures; indeed, they are positioned in many cases to have direct influence on what becomes an international pressure in the first place". Accordingly, we will compare two small media markets with focus on what private media managers expect from the state, meaning the policy makers, in a situation of intensified global competition. 


\section{Method and cases}

The analysis draws on elite interviews with upper management or CEOs in Norwegian and Flemish media companies. In total 20 elite interviews were conducted, 10 for each case, selected systematically to represent a comprehensive media ecology, as well as to be valid for a comparative study. The sample includes the two largest publishers (Schibsted and Amedia in Norway, Mediahuis and De Persgroep in Flanders), the two market-leading commercial television companies (TV2 and TvNorge in Norway; Medialaan and SBS in Flanders), two central production companies (a subsidiary of the Warner company in each market, plus Mastiff, which is part of Zodiak, in Norway and De Chinezen, a Flemish producer), two telecommunication incumbents as well as two additional distribution companies (Telenor Broadcast and Get in Norway; Proximus and Telenet in Flanders) ${ }^{1}$, two online journalism initiatives (In Norway, Agenda magazine, attached to a political think tank and Harvest, a niche magazine for outdoor lifestyle, and Apache.be and Newsmonkey in Flanders). This type of information-oriented selection is considered most relevant in qualitative inquiries as the goal is to maximise the usefulness of information obtained (Brinkmann, 2013, p. 57).

Elite interviews are challenging, because the informants tend to offer corporate talk, and their answers are likely to be crafted to give the strategically most advantageous image. The interview guide was semi-structured and designed to address both principal and general reflections, and examples of how media companies act in policy processes. The interviews were conducted in 2016, lasted about an hour, and took place at the offices of the informants. ${ }^{2}$ Interviews were recorded and transcribed, and systematically analysed from a bottom-up, inductive perspective (Brinkmann, 2013, p. 62), in which we identified three main thematic subjects, relating to expectations, experiences and explanations, which will be dealt with in each of the following sections.

\section{Global tech companies: "The government has a role to play"}

A profound finding was that all the media managers interviewed for this study regarded the competition from the global platforms as their most urgent challenge. In particular

\footnotetext{
1 The telecommunications incumbents are still majority state owned, but with considerable private ownership in both markets.

${ }^{2}$ Interviews in Norway were conducted by Gunn Enli and Linda Therese Rosenberg. Interviews in Flanders were conducted by Karen Donders and Tim Raats.
} 
media companies in newspaper publishing, broadcasting, TV-production and distribution sectors are concerned about how to sustain their income models and market shares. The emerging online initiatives are slightly less worried, and one online journalism initiative regards Facebook as more of a resource than a threat, for example by providing a free promotion channel (Harvest, Norway).

Yet, the large majority of the managers argue that their media businesses struggles as a result of the new disruptive competition, and we asked to what degree they thought that regulators could contribute to solve their problems. In general, the managers encourage policy makers to regulate digital platforms; they think government should secure a level playing field, meaning that they want similar policy frameworks. This point was most explicitly expressed by the CEOs of commercial television companies, indicating that the TV-industry is particularly affected by the competition from digital platforms:

If they (the government) can do something, it must be to aid Norwegian media companies in meeting the competition from the Netflixes of the world (TvNorge, Norway).

The government has a role to play (...) I still do believe in regulation. Media is too expensive to leave to the free market. (...). I believe that Europe can play a very important role, more than local governments (SBS, Flanders).

A key difference between the two markets was that while none of the Norwegian managers mentioned supranational regulation through the European Union (EU), this point was raised by two of the Flemish respondents. This shows that the Norwegian media leaders expects the national policy makers to be responsive to their call for regulation, while the Flemish managers expect the EU to develop more viable policies. In turn, this difference pinpoints that Scandinavian media policy is recognized by a high level of coregulation on a national level, while the Flemish media policy is more attached to the EU, and its increasing preference for self-regulation (Lievens, 2010, 2016). Moreover, the Norwegian managers might expect less of the EU than their Flemish counterparts because Norway is not a formal member of the EU and lacks the level of political influence equivalent to Flanders, even though the country is affected by EU rules as a member of the European Economic Area.

Despite Norway's paradoxical relationship with the EU, the managers in both media markets agree that policy making on a transnational level is needed to regulate digital 
platforms. In fact, the Norwegian informants went further than the Flemish in their suggestions for concrete policy instruments to secure a more equal playing field; in particular legacy media managers suggested taxing Facebook and Google to compensate for what they regard as unfair regulations. A parallel trend is that legacy media in both markets use the current watershed in media policy to argue for liberalized regulations on arenas such as advertising, copyright, and consumer rights, in order to harmonize with the platforms, confirming previous studies, arguing that stakeholders use times of digital disruption as a leeway to achieve liberalization of existing policy regimes (Freedman, 2008; Lund, 2016). A similar contrast was not found in the interviews with Norwegian respondents because these were less opposed to government intervention. This relates to the differences in media systems discussed in one of the sections above: Norway being rooted in the media welfare state, whereas Flanders's media system is more oriented towards economic protection as a means to safeguard local identity and Flemish language.

Despite consensus on the need for more political action, both Norwegian and Flemish respondents doubted the capacity of the various institutions to act. Particularly legacy media managers with close relations with policy makers question the regulatory power of the state and EU in relation to digital platforms:

This (regulating global actors) would however require a level of intervention which is hard to imagine that Norwegian politicians would manage (TV2, Norway).

Europe loses a lot of terrain today, especially in relation to the US and Asia. Europe doesn't bave a response to it because there is no level playing field between European and companies from other parts of the world (Proximus, Flanders).

In the next section we further investigate the stakeholders' experiences with policy makers, which also influenced the above described specific expectations.

\section{Media Policy: "We have a well-functioning dialogue"}

An insight from policy and management studies is that businesses' expectations towards policy makers are influenced by the policy instruments and how they are designed to shape the structure of media systems, but also their own strategic efforts to influence these instruments (Dimmick, 2003; Freedman, 2008; Lund, 2016). In spite of scepticism towards 
policy makers among many media managers, the efficient way to approach media policy is often to collaborate with policy makers and the government, according to Lund (2016, p. 118), who advises managers to exploit the policy makers' invitations to stakeholder involvement and to strategically influence policy. As such, we might expect that the media managers interviewed for this study have experienced collaboration with policy makers.

The analysis demonstrates that media managers in Flanders and Norway have in common that they acknowledge the importance of dialogue with policy makers, and that they have positive experiences with the approachability of policy makers. Respondents acknowledged that their opinions were heard, that policy-makers could be accessed by them and related this to the size of the market, which according to them ensures a shorter distance between those subject to and those forming policies.

I think that the policy makers in this country are very accessible. We do not always get what we want, but it (the dialogue) evolves in a constructive way (SBS, Flanders).

We have a well-functioning dialogue. We have the possibility to be heard on all kinds of issues. And it is not difficult to get access to the politicians (Schibsted, Norway).

However, the Flemish media managers were significantly more sceptical about the actual outcome of the dialogue compared to the Norwegian media managers. This scepticism was particularly evident in three ways, of which the first was based on a notion of independence and a principle of commercial autonomy. The Flemish respondents for example argue that they themselves are better qualified that the regulators in terms of protecting their brand. The second reservation concerned a low assessment of the policymakers; Flemish managers saw politicians as being devoid of vision, expressed by the CEO of a major production company:

The government says there is still as much money given to the sector, but they have no vision (...). The bottom line is that the money will no longer end up in the sector. So we are going to see a shrinkage (Warner Bros, Belgium).

A third type of criticism was typically raised by one of the online journalism firms in Flanders, who argued that policy makers suffer from path dependency as they tend to proritize support for legacy media above online journalism initiatives: “There are several 
government measures that discriminate against smaller media, especially digital media" (Apache, Flanders). There is indeed a longstanding relation between major legacy media players in Flanders and Norway, and the respective local policy makers, which might have resulted in policy capture and a higher priority given to their issues to the detriment of smaller companies that have less political leverage.

Equivalents to the two first types of criticisms were not found in the interviews with Norwegian management, while a milder and less critical form of the third argument was raised by the managers of online journalism initiatives in Norway, which indicate that digital newcomers are outside the business-state dialogue circuit. This approving attitude towards Norwegian media policy, even among those managers who did not receive any state support, were related to a general cross-sector experience with media regulation as a legitimate and efficient way of securing the Media Welfare State.

The higher level of positive expectations of policy making among the Norwegian media managers is related to their experiences with participating in policy processes of coregulation. The most prominent of these policy processes has in recent years been the introduction of a platform neutral zero-VAT regime, extending the arrangement to include not only print media, but also online news. Among the most active stakeholders in this policy process were, of course, newspaper publishers, but also television companies, praise the regulatory measure as an important tool to protect the national newspaper industry:

Among the most important changes is zero-V AT for digital news - an important media policy scheme.

Several Norwegian newspapers would probably not have survived without it (TV2).

The platform neutral zero-V $A T$ has been extremely supportive for media innovation (Amedia).

Zero-VAT for digital news is the most crucial policy change during the last five years. We managed to get support for our argument that the digital readers should not be treated differently than the print readers (Schibsted).

The media industry collaborated extensively with policy makers in the process of interoducing the new zero-VAT measure; they communicated their perspectives and interests, but also internalized key policy goals. The collaborative aspect of the process is an expression of the co-regulation and cooperative structures characterising Norwegian policy making. A criterion for this co-regulation is a high degree of mutual trust, which 
was indeed expressed by one of the informants representing the Norwegian newspaper industry: "We are highly trusted because we base our arguments on facts" (Amedia). Similarly, with reference to the tradition of co-regulation, the CEO of a television company underlined the importance of engaging in policy processes:

In Norway, there is a tradition that you must listen before you make a decision, and so it is up to us to be active on the various arenas before decisions are made (TV2).

The company has achieved key advantages by collaborating with the state (Sjøvaag, 2011). The CEOs and top-level managers of legacy media companies also mentioned trade bodies for journalist, editors and media companies as highly important for the, for them, advantageous outcome of the policy process.

This leads us to the second reason for the acclaim of the platform neutral zeroVAT: the financial aspect, which is in turn related to the normative framework for media in the Norwegian constitution, as well as the high level of public spending on media in the Nordic region, and particularly in Norway. The CEO in the publishing house Schibsted expressed an expectation of the state to support the company's news business: "We wanted a subsidy for keeping the population updated through written texts, printed or digital. Norway is a small country where it is important that we sustain the Norwegian culture and identity through the news media".

Lastly, the zero-VAT case was special because of the cross-sector aspect, meaning that the process involved stakeholders and interest groups from a variety of sectors, including also media players which do not benefit from VAT-reduction. This case shows that the private media companies can achieve their policy goals more efficiently if they work together and maintain internal consensus, confirming studies showing that lobbyism is more efficient when stakeholders cooperate (Baumgartner et al., 2017). In summary, this case indicates that the managers' experience with collaborative and supportive policy making lay the ground for further trust in policy makers to support them in their competition with digital platforms. However, the media managers must adjust their expectations according to their status as private commercial players, as opposed to public media. In the next section, we will investigate the managers' views on public service broadcasting. 


\section{Public Service Broadcasting: "The elephant in the room"}

Regulation of PSB in relation to private media and digital platforms has been an emerging topic in policy studies for more than a decade (Enli, 2008; Moe, 2008; Brevini, 2013, Bondebjerg, 2016). Private media stakeholders increasingly argue that public funding of broadcasting is creating an uneven playing field; PSB is subsidized while the private companies relate to more unpredictable economic realities. A key debate is to what degree PSB institutions should be given leeway to expand online, and in an attempt to reduce competition from publicly funded institutions, the private commercial media have "declared war against the PSB online activities and approached politicians to remove it from the PSB remit" (Bondebjerg, 2016, p. 188). In fact, such lobbyism from private broadcasters and publishers has impacted on EU policy-making for the media (Brevini, 2013). The implementation of the 'ex ante' test, which requests an evaluation of all new PSB-services, to avoid that such services harm private competition, is described as a direct "reaction to deal with aggressive private sector lobbying against a new media remit for public broadcasters" (Donders, 2011, p. 30). However, there are significant national and regional variations regarding how much leeway PSBs are given by governments to expand online and to exploit commercial markets (Enli, 2008; Iosifidis 2010, Brevini 2013, Gulyars and Hammer, 2013, Ibarra et al., 2015).

In Flanders and Norway, the PSB institutions have gained acceptance for online expansion, and have exploited opportunities through technological innovation (Van den Bulck \& Moe, 2017). The persistent regulatory argument is that, especially in small media markets, an all-commercial media system would result in media failure (Moe, 2008; Larsen 2011; Doyle, 2013). However, there are significant tension between PSB and private media, and regulators face challenges in their attempt to regulate both private and public media to complement each other, while both serving the public interest (Ohlson \& Sjøvaag, 2018). This challenge has escalated as a result of digital platforms, not least because private media consider themselves unfairly regulated both in relation to the digital platforms and the PSBs. A key finding was that the managers in both markets were critical of the PSBs position as state funded, yet commercial competitors. In particular, newspaper publishers and television companies in competition with the PSBs, expressed concerns for the public institutions' expansive strategies, and argued that policy makers should reduce their remit to secure diversity: 
NRK is more and more the elephant in the room. NRK is in some areas threatening diversity (Amedia, Norway).

I think the government is on the ball on most issues, but when it comes to NRK, they should have been limited in some areas (Schibsted, Norway).

NRK is taking a little too large piece of the commercial media cake, and they could reduce the amount of popular entertainment (Warner Bros, Norway).

Public broadcasting should preferably be market-supportive and any form of market distortion must be ruled out (Medialaan, Flanders).

Despite this unison scepticism among the management of legacy media in both markets, a second key finding was that the Flemish managers, as a rule, were more critical against the PSBs privileges than the Norwegian managers. A typical trait in the interviews with the Norwegian managers was that they expressed praise and admiration of the public broadcaster. Managers across different media-sectors characterized the NRK's content as high-quality, innovative and diverse. A similar praise of PSB was not found in the Flemish interviews, as these were less appreciative and more critical towards the public broadcaster. This comparatively higher level of criticism was most explicit in the managers' opinions about paid online PSB-services; while none of the Norwegian managers supported this suggestion because they agreed with policy makers that all PSB content should be free, Flemish managers across very different media sectors supported paid PSB online services:

I do have a problem that the public broadcaster can offer the same content online for free, while we must deliver it in a paying system. There is a lack of vision in the government (Mediahuis, Flanders).

We do not think everything should be for free. (...) So, we think that a public broadcaster may offer payment services (Telenet, Flanders).

The intensified competition from digital platforms like Google and Facebook has changed the Norwegian media policy debate because it has strengthened private media companies' arguments that the publicly funded company is intruding their markets. In an opinion piece 
written by some of our informants, the private media CEOs suggest that policy makers should rethink the PSBs financial support to avoid direct competition with commercial players, but they also want the NRK to remain a strong institution (Ryssdal et al. 2018). Recent policy developments indicate that the government have listened to the arguments, as they are suggesting new ways to distribute public funding, making it possible for other players than the NRK to "get a piece of the cake". Still, there is political consensus that the NRK should remain a strong institution, a consensus confirmed by our informants.

Given the more critical attitude towards PSB among the Flemish informants, there is a significant difference between how private media businesses in the two media markets relate to the existing policy regime. This might be explained by the Norwegian model for co-regulation, and a tradition for collaborative policy making and arrangements which also benefit the private media sector financially.

\section{Media policy for private media in the age of digital platforms}

Digital platforms such as Google, Facebook and Netflix have caused a watershed moment for policy, as well as for economics and journalism. This article contributes to the debate about how the growth of digital platforms with global outreach impact on the relation between policy makers and media companies in distinct media markets. Taking the perspective of the private media sector in two small European media markets, Flanders and Norway, we ask: to what degree does private media management expect the policy makers to support them in the intensified competition from digital platforms?; how does these expectations relate to previous experiences with policy makers as regulators or collaborators?, and what explains the differences between the Norwegian and Flemish cases?

Drawing on 20 elite interviews with CEOs and upper management in Norwegian and Flemish media companies and complementary desk research, we found that digital platforms are indeed regarded as a threat to private media in small European markets. Particularly legacy media companies encourage policy makers to protect domestic media companies against global competition. Even companies which were reluctant to be regulated themselves, were in favour of regulating digital platforms.

However, the informants were doubtful about the regulatory power of national, or EU policy makers, in relation to the digital platforms. Comparing the two cases, we found that the Norwegian legacy media managers expected more of the national policy makers than the Flemish. This might be explained by the more national orientation of Norwegian 
media policy, given that Norway is not a member of the EU, but relate to EU law as a member of EEA, with and limited means to influence European policy making. In contrast, Flanders is a federal state within the EU. Even when this difference is accounted for, the Norwegian managers express higher trust in policy makers as collaborators compared to their Flemish counterparts. A key explanatory factor might be the preference for co-regulation in Norwegian policy making, which has benefitted private media financially.

Small media markets are particularly vulnerable to international pressures, and as demonstrated in this study, two main alternatives for policy makers emerges; first, they can provide equal playing fields by entering a 'spiral of privatized regulation' (Wagner, 2018, p. 223), where self-regulation replaces co-regulation, and the role of the state becomes more remote. Second, they can co-regulate the private media companies, and provide privileges and frameworks which have previously been reserved for the PSB companies.

Given that these findings are based on a study of Flanders and Norway, a key question is to what degree they are representative for other media systems, especially because there are still significant differences between for example Northern and Southern Europe (Siegert, 2006; Isofidis, 2010). Several studies revisiting Hallin and Mancini’s (2004) argument that all media systems converges towards a 'liberal system', and found continuous differences between media systems, and that convergence towards a more 'liberal system' was more of a trend in the first phase of commercial television in Europe, than in recent phases (Ohlsson, 2015; Hallin \& Mancini, 2014; Voltmer, 2012). As shown in these contributions, media policy matter, even in the context of digital platforms. The future of media markets that are "small among giants" (Lowe et al., 2011) will be determined by the choices made by policy makers in this early phase of the regulatory disruption. 


\section{References}

Aalberg, T. \& Curran, J. (Eds.). (2012) How media inform democracy. A Comparative Approach. New York and London: Routledge.

Allern, S., \& Pollack, E. (2017). Journalism as a public good: A Scandinavian perspective. Journalism. Online first. doi:10.1177/1464884917730945

Barwise, T. P., \& Watkins, L. (2018). The evolution of digital dominance: how and why we got to GAFA, pp.21-50 in Moore, M. \& Tambini, D. (Eds.). (2018). Digital Dominance. The power of Google, Amazon, Facebook and Apple. Oxford University Press.

Baumgartner, F. R., Berry, J. M., Hojnaciki, M., Kimball, D. C., \& Leeck, B. L. (2017). Lobbying and Policy Change: Who Wins, Who Loses, and Why? Chicago: University of Chicago Press.

Bell, E. (2018). The Dependent Press. P.241-265 In Moore, M. \& Tambini, D. (Eds.). Digital Dominance: The Power of Google, Amazon, Facebook, and Apple. Oxford: Oxford University Press.

Benson, R. \& Powers, M. (2011). Public Media and Political Independence: Lessons for the Future of Journalism from Around the World. New York: Free Press.

Bondebjerg, I. (2016). PSB 3.0: TV and the Digital and Global Challenge. Nordicom review: Nordic research on media \& communication, 37, 185-191.

Brevini, B. (2013). Public Service Broadcasting Online. A Comparative European Policy Study of PSB 2.0. London: Palgrave.

Brinkmann, S. (2013) Qualitative interviewing: Understanding qualitative research, Oxford, Oxford University Press.

Brüggemann, M., Engesser, S., Büchel, F., Humprecht, E., \& Castro, L. (2014). Hallin and Mancini Revisited: Four Empirical Types of Western Media Systems. Journal of Communication, 64(6), 1037-1065. doi:10.1111/jcom.12127

Conti, G. (2009). There's a fly in my digital soup. netWorker, 13(2), 32-ff.

Coyle, D. (2018). Practical competition policy implications of digital platforms. Bennett Institute for Public Policy working paper, (01).

Davis, C., \& Zboralska, E. (2017). Transnational over-the-top media distribution as a business and policy disruptor: The case of Netflix in Canada. The Journal of Media Innovations, 4(1), 4-25.

d'Haenens, L., Antoine, F., \& Saeys, F. (2009). Belgium: Two communities with diverging views on how to manage media diversity. International Communication Gazette, 71(1-2), 51-66.

Dimmick, J. (2003). Media Competition and Coexistence. The Theory of Niche. Mahwah, N.J.: Erlbaum Associates. 
Doyle, G. 2013: Understanding Media Economics. Second edition. London: Sage.

Donders, K.., Van den Bulck, H. \& Raats, T. (2018) The politics of pleasing: an analysis of Flemish media policies on public service media. Media Culture and Society. Vol. 41(3): 347-366.

Enli, G. (2008) Redefining Public Service Broadcasting: Audience Participation and Multi Platform Formats. Convergence. Vol. 14 (1): 105-120.

Evens, T. \& Donders, K. (2018) Platform power and policy in transforming television markets. Palgrave Macmillan.

Freedman, D. (2008). The politics of media policy. Malden, Ma: Polity Press.

Flew, T., Iosifidis, P., \& Steemers, J. (eds). 2016: Global Media and National Policies. The Return of the State. Basingstoke Palgrave McMillan.

Gulyas, Á. \& Hammer, F. (2013). Public Service Media in the Digital Age: International Perspectives. Newcastle upon Tyne, UK: Cambridge Scholars Publishing.

Hallin, D. C., \& Mancini, P. (2004). Comparing media systems: Three models of media and politics. Cambridge: Cambridge University Press.

Hallin, D. C., \& Mancini, P. (2017). Ten years after comparing media systems: What have we learned?. Political Communication, 34(2), 155-171.

Hall, P. A. \& Soskice, D., (2001). An Introduction to varieties of capitalism. In Hall, P. A. and D. Soskice (Eds.). Varieties of capitalism. The Institutional Foundation of Comparative Advantage. Oxford: Oxford University Press.

Helberger, N., Kleinen-von Königslöw, K., \& van der Noll, R. (2015). Regulating the new information intermediaries as gatekeepers of information diversity. info, 17(6), $50-71$.

Ibarra, K. A., Nowak, E., \& Kuhn, R. (2015). Public service media in Europe: A comparative approach. Abingdon: Routledge.

Iosifidis, P. (2010). Reinventing Public Servvice Communication. European Broadcasters and beyond. Basingstoke: Palgrave Macmillan.

Isofidis, P. (2016). Globalisation and the Re-emergence of the Regulatory State. In T. Flew, P. Iosifidis \& J. Steemers (Eds), Global Media and National Policies. The Return of the State (pp. 16-32). Basingstoke: Palgrave McMillan.

Larsen, H. (2011). Public Service Broadcasting as an Object for Cultural Policy in Norway and Sweden. A Policy Tool and an End in Itself. Nordicom Review 23(2): $35-47$. 
Lievens, E., Dumortier, J., \& Ryan, P. S. (2006). The co-protection of minors in new media: A European approach to co-regulation. UC Davis J. Juv. L. \& Pol'y, 10, 97.

Lievens, E. (2010). Protecting Children in the Digital Era: The Use of Alternative Regulatory Instruments. Leiden, Netherlands: Martinus Nijhoff.

Lowe, G. F. \& Nissen, C.S., (2011). Size Matters for TV Broadcasting Policy. In Lowe, G. F. \& Nissen, C. S. (Eds.), Small Among Giants. Television Broadcasting in Smaller Countries (pp. 21-43). Göteborg: Nordicom.

Lund, A. B. (2016). A Stakeholder Approach to Media Governance. In Lowe, G. F. \& Brown, C. (Eds.). Managing Media Firms and Industries, Media Business and Innovation (p.103-120). Springer International Publishing.

Lynskey, O. (2017). Regulating 'platform power'. Law, Society and Economy Working Papers. LSE.

Mansell, R. (2015). Platform Power. Intermedia, 43 (1) pp. 2-24.

Moe, H., (2008). Public Service Media Online: Regulating Public Broadcasters' Internet Service - A Comparative Analysis. Television and New Media 9(3), 220-238.

Moore, M. \& Tambini, D. (Eds.). (2018). Digital Dominance. The power of Google, Amazon, Facebook and Apple. Oxford University Press.

Napoli, P. M. \& Caplan, R. (2017). Why Media Companies Insist They're Not Media Companies, Why They Are Wrong and Why It Matters, First Monday, 22(5).

Naughton, J. (2018). Platform Power and Responsibility in the Attention Economy. In Moore, M. \& Tambini, D. (Eds.). Digital Dominance: The Power of Google, Amazon, Facebook, and Apple. Oxford: Oxford University Press.

O'Regan, T., \& Goldsmith, B. (2006). Making cultural policy: Meeting cultural objectives in a digital environment. Television \& New Media, 7(1), 68-91.

Ots, M., Krumsvik, A. H., Ala-Fossi, M., \& Rendahl, P. (2016). The shifting role of value-added tax (VAT) as a media policy tool: A three-country comparison of political justifications. Javnost - The Public, 23(2), 170-187.

Ohlsson, J. (2015). The Nordic media market. Göteborg: Nordicom.

Plantin, J. C., Lagoze, C., Edwards, P. N., \& Sandvig, C. (2018). Infrastructure studies meet platform studies in the age of Google and Facebook. New Media \&o Society, 20(1), 293-310.

Puppis, M. (2009). Media Regulation in Small States. International Communication Gazette, 71(1-2), 7-17. https://doi.org/10.1177/1748048508097927

Puppis, M. \& Künzler, M., (2013) Private Television in Small European States: Ireland, Austria and Switzerland. In Private Television in Western Europe. (pp. 85-101). Palgrave Macmillian, London. 
Puppis, M., d'Haenens, L., Steinmaurer, T., \& Künzler, M. (2009). The European and global dimension: Taking small media systems research to the next level. International communication gazette, 71(1-2), 105-112.

Ryssdal, R. E., Stokstad, A., Sørsdahl, D., Koch, A., Lund, K. S., \& Øgrey, R. (2018). NRK i ferd med a bli en alvorlig trussel. (NRK is turning into a serious threath).Dagens Naringsliv. August 14th.

Siegert, G. (2006) The Role of Small Countries in Media Competition in Europe', in Heinrich, J. and Kopper, G. (eds.) Media Economics in Europe. Berlin: Vistas.

Syvertsen, T.,Enli, G.,Mjøs O. J. \& H. Moe (2014): The Media Welfare State: Nordic Media in the Digital Era. Michigan: Michigan University Press.

Tambini, D., \& Labo, S. (2016). Digital intermediaries in the UK: implications for news plurality. info, 18(4), 33-58.

Trappel, J. (2011). Structure and dynamics. The television broadcasting industry in smaller countries. In Lowe, G. F. \& Nissen, C. S. (Eds.), Small Among Giants.

Television Broadcasting in Smaller Countries (pp. 111-129). Göteborg: Nordicom.

Van den Bulck, H., \& Moe, H. (2017). Public service media, universality and personalisation through algorithms: mapping strategies and exploring dilemmas. Media, Culture \& Society, 40 (6): 875-892.

Voltmer, K. (2012). How Far Can Media Systems Travel, pp. 224-245, in D. Hallin \& P. Mancini (Eds.), Comparing Media Systems Beyond the Western World.Cambridge: Cambridge University Press.

Wagner, B. (2018). Free Expression? Dominant Information Intermediaries as Arbiters of Internet Speech. In Moore, M. \& Tambini, D. (Eds.). Digital Dominance: The Power of Google, Amazon, Facebook, and Apple. Oxford: Oxford University Press. 